\title{
Generation of University Spin Off Companies: Challenges from Mexico
}

\author{
Pilar Pérez-Hernández ${ }^{1 *}$, Guadalupe Calderón ${ }^{2}$ Emilio Noriega ${ }^{1}$
}

\begin{abstract}
Spin off companies refer to firms created by university laboratories, the generation of this type of companies has a pull effect through the diffusion, imitation and innovation of the company even at long-term for economic development. In order to generate this type of business, an articulated set of legislative, cultural and financing, instruments are required. In addition, various actors must be involved; aligned to achieve local development. The ability of universities to create spin off companies depends on their background and favorable regional conditions. This research aims to identify the main challenges during spawn university spin off companies in Mexico, thus, it is necessary explore the consequences and analyze key factors of entrepreneurial university scheme, at the end of this paper illustrates Mexico's outlook and the conclusions. There are four major challenges that universities faces: first, the lack of clear and effective internal regulations and paperwork processes for intellectual property management and proper commercialization strategies for technological developments; second, is not hiring specialists for Technology Transfer Offices at Higher Education Institutes (HEI) and Public Research Centres (PRC) to generate capabilities; third, inherent complexities of business training and entrepreneurship education, to enhance management competences and business venture, and fourth, decision-maker authority at HEIs and PRCs must develops an enabling environment as governance mechanisms that support and prioritize such processes, so that could be translated into punctual actions with concrete results.
\end{abstract}

Keywords: University spin off companies; Mexico; challenges.

Submitted: March 23 ${ }^{\text {rd }}, 2021 /$ Approved: April 24 $4^{\text {th }}, 2021$

\section{Introduction}

The innovation capacity of a country or region is closely linked to its capacity for creating, valuing and disseminating knowledge. In this context, the university has had to find new ways of gathering the knowledge generated and meet society and market needs, which constitutes a change in its functions, insofar has been led to play an active role in the economic and social scene.

Accordingly to Chesbrough (2006), creating new products and services requires growing and diverse sources of creativity, which is why companies require, cooperate with clients, suppliers, universities and even competitors. Because of this, universities are preferred partners for new technological fields researches, where business results are uncertain. But this cooperation is even more necessary in developing countries, where universities are the main source of knowledge for innovation (Stal et al., 2016).

In this context and generalizing, universities are recognized as sources of innovation, basically, for two reasons: first, the publication of research results in scientific journals and corporate contracts, so innovation results used to be under company responsibility and universities would have not retain intellectual property rights. Yet, universities began to retain ownership and exploit protectable and marketable inventions based on their research results through business licensing and new business creation (Thorburn, 2001; Lockett et al., 2005, Grandi \& Grimaldi 2005; Beraza \& Rodríguez, 2010; Narváez et al., 2016).

In developed countries, universities and companies are natural partners, as companies seek external sources of knowledge to complement their human resources and research and develpment (R\&D) infrastructure. Technology transfer (TT) mechanism through spin off companies has had important advances and contributions to the economy, particularly in the United States (US), it is one of the most relevant due to the number and impact of university spin off companies created (Di Gregorio \& Shane, 2003).

The term spin off companies was born in the US in the late 1970s, to refer to spontaneous and independent companies that emerged from university laboratories in California and Boston. In the eighties, the concept started to be used in Europe,-in middle of industrial reconversion processes (Lockett et al., 2005; Bueno, 2007; Narváez et al., 2016; García et al., 2017).

Likewise, TT could be feasible if production of knowledge is useful for economic purposes for companies and universities. TT is defined as the displacement of such knowledge from the place of its production to that of its use. The creation of university companies has achieved great relevance among the TT instruments of the university to society, compared to other mechanisms such as research contracts or the sale of patents (García et al., 2017).

University spin off companies have two types of impacts: a) direct, they are located close to emergence of technology, contributing to taxation and the possibility of competing internationally, driving changes in the university, facilitating the incorporation of graduated alumni, training entrepreneurs, making a better assessment of research results obtained, generating income that benefits the founders and the university; and b) indirect, enhancing TT mechanism, facilitating local economy growth, increasing university prestige, strengthening business and cooperation networks, promoting the use of advanced

(1) Centro de Investigaciones Económicas Administrativas y Sociales, Instituto Politécnico Nacional, Mexico City, México

(2) Universidad Autónoma Metropolitana unidad Cuajimalpa, Mexico City, México

${ }^{*}$ Corresponding author: mpperez@ipn.mx

ISSN: 0718-2724. (http://jotmi.org)

Journal of Technology Management \& Innovation (c) Universidad Alberto Hurtado, Facultad de Economía y Negocios. 
technologies, contributing to greater efficiency of innovation and regional economic development, or even as agents of outlook (Rodeiro et al., 2010; García et al., 2017; Di Gregorio \& Shane, 2003; Rasmussen \& Wright, 2015; Walter et al., 2006; Castillo-Vergara \& Alvarez-Marin, 2015). In other words, the creation of university spin off companies has a pull effect on society through mechanisms such as dissemination, imitation and innovation, incorporating best practices in technology management and other company departments, as well as in long-term economic development (Rodeiro et al., 2010; García et al., 2017).

The process of creating Technology-Based Enterprises (TBE) requires an articulated enviroment such as: government, universities, society, stakeholder, businessmen, economic, social cultural and political factors; these must be articulated to achieve local development environment. Furthermore it gathers endogenous development approach as part of a participatory conception (Perkmann \& Walsh, 2007; García et al., 2017).

Without ignoring the contribution of this mechanism, criticism has also been received, evidencing its reliance on new companies creation conditions and all drawbacks involved, as financial, technical and cultural (Jiménez et al., 2010). It is important to highlight that the universities prestige and licensing policies have a significant impact on these value creation processes (Di Gregorio \& Shane, 2003). The ability of universities to create spin off companies depends on their background and favourable regional conditions.

The aim of this research is to identify institutional challenges for the creation of university spin off companies in Mexico. The following methodology was used; analysis of the literature and findings, it was helpful for disseminating results and experiences in order to establish a starting point to delve into the topic for future research, either as a sectoral, regional or national-approach. For this purpose, the work is structured on four sections, the first of them explores the implications for entrepreneurial university schemes then analyzes key factors and challenges that spinoffs companies face, by the end of this paper recommendations are proposed.

\section{From entrepreneurial university to university spin-off companies}

The third mission of the universities is associated with the promotion of economic development, through TT and linkage between university and firms (Etzkowitz, 1993; Etzkowitz \& Leydesdoff, 2000). Authors like Slaughter \& Leslie (1997) and Slaughter \& Rhoades (2004) named this phenomenon as "academic capitalism", and others like Smilor (1987), Clark (1998) and Etzkowitz (1998) as an "entrepreneurial university". Entrepreneurial university needs to be managed as a business, merchandising their research results, whether as patents, as R\&D, agreements or eventually in the creation of companies. Entrepreneurial university is characterized by: 1) a management structure that guarantees the adaptation of the institution in a changing environment, blending traditional academic values and corporate values; 2) set of entities (business and administrative) developed by the university to interact nimbly to the environment; 3 ) a diversified financial base, which would reduce dependence on a single source of resources, increasing its autonomy; 4) a motivated academic body that catalyses entrepreneurial activities, and 5) an entrepreneurial culture (entrepreneurial "ethos"), that is, a set of habits or beliefs that define a business community made up by its leaders, academics and students mingling with their surrounding, their decision-making processes, and provides an incentive structure for their community to start new ventures (Etzkowitz, 2008; Stal et al., 2016).

The literature studies the capacity of universities to create companies, and takes the resource-based theory approach of Penrose (1956) up, where a key role in the creation of companies is due to accumulated results and skills by each institution through experience, such factors will constrain their future results (Rodeiro et al., 2008). This type of university encourage the creation of companies in its laboratories and its facilities, triggering a new type of university staff and a new type of researcher; an entrepreneur scientist. In addition, there must exist what Clark (2004) named "entrepreneurial champions," resulting from the integration of key aspects of entrepreneurship training throughout the curriculum and the determined pursuit of interdisciplinary research and development. For this reason, he expressed the need to develop structures for the promotion of entrepreneurship and the creation of companies based on the research carried out by research groups (Santamaria \& Brunet, 2007).

Academic entrepreneur appears as an important figure, with the growth of business incubators located in universities. The acquisition of licenses continues to be the most common tool to commercialize the intellectual property of universities. The changes in the legislation through the Bayh-Dole Law (1980), which transfers intellectual property of research carried out from public funds, and the creation of Technology Transfer Offices (TTO), have caused TT spread more easily (Kenney \& Patton, 2011; Siegel et al., 2007; Stal et al., 2016). As well as the transfer of research results to the market, as a source of development and competitiveness (Etzkowitz et al., 2000; Mowery \& Sampat, 2001; Shane, 2004), in which a wide variety of agents participate (Freeman, 1987; Cooke, 1992; Breschi \& Malerba, 1997; Edquist, 1997; Etzkowitz et al., 2000). Aware of these difficulties, universities and governments have begun to establish policies to promote it (OECD, 1999; Beraza \& Rodríguez, 2011).

Numerous studies have highlighted the role of universities as potential incubators for TBE and the relevance of linking scientific knowledge with educational requirements in educational programs (Delmar \& Davidsson, 2000; Vesper \& Gartner, 1997). Spin off companies are part of the university's TT strategy, they have become one of the objectives of academic authorities, since TBEs are based on university knowledge and put into perspective the importance of its role in knowledge economy (Rodeiro et al., 2010).

Besides, it should be noted, first, that spin off companies are located close to their origin and so facilitate local economy growth. Second, promoting changes in the universities facilitating the incorporation of graduates from undergraduate and graduate levels, creating a 
knowledge market with highly qualified human capital, and improving a better assessment of research results obtained. Third, generating capital transfer income that benefits founders and universities, since those spin-off companies that reach a high level of development can place part of their capital in a strategic investment or make an initial public offering. Fourth, having an important role in the innovation process, generating qualified employment and contributing to economic development, since their products and technologies have high added value, their R\&D and innovation activities lead to economic development (Etzkowitz, 1998; Etzkowitz et al., 2000; OECD, 2001 and 2003; Santamaria \& Brunet, 2007; Iglesias et al., 2012).

\section{Characterization of university spin off companies}

It's necessary explain the concept of university spin off, this has evolved largely due to the empirical contributions of themselves. For Pirnay et al. (2003), academic spin off arises from the knowledge generated by academic research, with the participation of academic staff. On the other hand, Djokovic \& Souitaris (2008) affirm that these firms have evolved from academic knowledge, but were not necessarily created by the same stakeholders involved at the beginning. Because academic staff involved in the research may not be interested, and a colleague, a graduate student or even a person not related to the university is who decides to take the risk. Some common attributes of spin off companies are their academic origin; the exploration of inventions, patented or not, and also the knowledge accumulated by researchers in academic activities. These kind of firms are for-profit entities and independent from universities, spawned by at least one member of the university community (Stal et al., 2016). Therefore, in this research, university spin off companies will be understood as business initiatives promoted by members of the university community that base their activity on the exploitation of new processes, products or services with high added value, based on the knowledge acquired and the results obtained at the university itself through R\&D and innovation, resulting in business development and economic growth that affects the competitive improvement of the productive sector as a whole.

The difference between spin off and start-up companies is that the first of them maintains a relationship with the university, by licensing contract, joint $\mathrm{R} \& \mathrm{D}$ projects, university staff may or may not continue working for it. While start-ups are generated by university students, but do not have relationship with their alma mater.

Besides, analyzing university spin off creation process or the different stages of this process, some authors propose that it is an idea based on a technology generated from research, protected by patents and transferred to a new one company for its commercialization. However, there is no consensus for the number of stages, their name and the starting point. The idea of a standardized linear spin off process is questionable, as it limits the understanding of this phenomenon and block the implementation of boosting policies. The TT process is becoming more interactive. The driving force behind the creation of an TBE comes basically from its network of relationships (Mustar, 2001; European Commission, 2002; Beraza \& Rodríguez, 2011)
Furthermore, Pirnay (2001) identifies the degree of university involvement at the different stages, it is shown that the participation of the university is essential in the early stages of the creation and-gradually loses presence, that does not mean university cannot be involved for the last stages, but there are other stakeholders (financial entities, science and technology parks, business incubators, etc.) that can promote their development more effectively and efficiently (Beraza \& Rodríguez, 2011).

In the majority of universities, the research groups that gave the seed idea for the creation of a company usually assume the roles that have been assigned to them, as: shareholding, TT by royalties, consultancy in technological strategy, assistance for new developments (Beraza \& Rodríguez, 2011).

Leadership in promoting spin off companies is assumed, in the first place, by members of research groups; secondly, postgraduate-doctoral students; and thirdly, people hired abroad. In some European universities, leadership is identified in the TTO staff or business development managers employed by the university (Beraza \& Rodríguez, 2011).

Even in developed countries, the creation of university spin off companies is located in some universities that have a strong entrepreneurial bias. American universities, on average, generate 1.91 spin offs per year, while MIT has already created 31 in a single year, being its main form of TT (O'Shea et al., 2005). Several investigations have described success factor for the creation of spin off as a source of TT. These can be grouped into four main types: the existence of venture capital, the type of knowledge, the type of university, and the research prominence (García et al., 2017).

However, the effective management of success factors for a new company and its adequate correspondence with environment variables, boosts competitiveness levels of the economic activity and achieve an impact on the sector and the region, which returns as benefits for the university.

Walter (2006) points out that it is necessary to consider two aspects: a) the logic search for a creative relationship between university and company, which must be characterized by the recognition of the different nature of work and objectives; for the respect of these singularities and for the search for mutual benefits; b) the response of universities to requests for new technological pattern: from a production model that had routines as a goal, to a model that sees in constant technological change as its main routine (García et al., 2017).

In general in Europe university TT systems have been consolidated. Similarly, a significant number of universities have an assistance program for the creation of TBE. Although the importance of these has grown, there is still insufficient data to confirm that university spinoffs generate more innovation and better employment compared to other types of companies (Iglesias et al., 2012).

Not all university spin offs manage to get out of the protection of the university and have a successful autonomous performance, this limits the expectation of job creation and economic development related to 
the creation of this type of companies and has led to the realization of various studies that try to deepen the understanding of the phenomenon.

\section{Ecosystem for the emergence of spin off companies}

The governments of various countries, aware of the value of knowledge and research commercialization and to impact the development of the economies, promote policies in this sense. Changes have been generated in the legislation that regulates university TT, such as the Bayh-Dole law in the US, required to universities establishing an OTT, with greater attention to academic patents and for granting of licenses. This promoted a favourable environment for university entrepreneurship, whose evolution has allowed leading universities to develop strategies to link with the environment, becoming interactive centers for companies and other society organizations seeking solutions. In the period 1980-2005, the creation of more than 4,543 biotechnology companies in US universities, hospitals and research centers were reported, as the introduction of 50 high-tech products in the market and an exponential increasing in patents granted an average of $8 \%$ compared to the previous year (Jiménez et al., 2013).

Outside of the US, changes in academic commercialization are linked to more general reforms. In United Kingdom and Netherlands during the 1990s. In France the so-called Loi Allègre of 1999 was enacted. In this sense, Swedish government has been making efforts to promote the commercialization of academic technology since the early 1980s. Italy displaced powers from the central government to the universities. Furthermore, Denmark, Germany, Austria and Norway amended their intellectual property laws to grant rights to universities in a similar way to the Bayh-Dole Act. Other nations are carrying out similar reforms (Castillo-Vergara \& Alvarez-Marin, 2015; Grimaldi et al., 2011).

There are many decisive factors at the creation of spin offs, these can be the environmental and the contact networks, supporting schemes and financial infrastructure, type of technology, intellectual property, characteristics of the founders, internal regulations, conflicts of interest, management skills, etc. The creation of new TBEs and the consolidation of the private sector in the economy is a sure way to increase economic performance. Furthermore, market solutions offer the opportunity to create substantial and significantly positive change also within the configuration of material wealth (Bruton et al., 2013). The development of these types of transfers not only provides mentioned benefits, it is shown a positive relation between the ability of attracting financial resources. Success cases like Massachusetts Institute of Technology (MIT) can be impossible to imitate. A 1997 study by the Bank of Boston identified 4,000 spin-off companies from MIT employed 1.1 million people and generated $\$ 232$ billion in annual sales worldwide. However, many investigations show that most of them fail in the process of growing successfully in their sector in countries outside Europe or North America (Conceição et al., 2012).

Bercovitz et al. (2001) highlight that most of the universities with high levels of university-business interaction use a decentralized TT model, the creation of spin offs. Lockett et al. (2003), find a positive relationship between coworking networks in a university and its spin off activity, as between university's participation in the capital of these companies. Powers and McDougall (2005) also find a positive and statistically significant relationship between TTO experience and its spin off activity. Lockett \& Wright (2005) found that the number of spin offs created at United Kingdom universities is positively associated with the number of people who are part of the TTO (Beraza \& Rodríguez, 2011).

In the universities from the point of view of the university administration and the organizational considerations related to support policies implemented by universities, the existence of a low level of innovative culture and TT, recent creation of support programs for spin off spawn was manifested in limited support policies in terms of capacities, resources and results (Pirnay, 2001; Beraza \& Rodríguez, 2011). In Latin America, the regulation on the creation of spin off companies is still being built, which may cause conflicts of interest between academics and researchers, even when they do not have participation in them. It is established that the current legislation of the countries can constitute a disincentive for its creation.

\section{Challenges in generating university spinoffs in Mexico}

The literature emphasizes the institutional aspects of generating spin off companies in a university, since this is a reflection of their institutional behavior. Those universities that have a culture that supports the commercialization of their research results will obtain better results in TT activities and the creation of spin offs. Likewise, they highlight that critical factors for the success of TT (adequate institutional environment, organizational culture, institutional leadership, appropriate incentive system, level and orientation of the investigation, legal context) cannot be solved by the intermediation structures by themselves (Roberts, 1991; Polt et al., 2001; Beraza \& Rodríguez, 2011).

One reason a university may not have a culture of support for spin off activity is the incentive system, specifically, potential conflicts between incentives to publish or market research results (Thursby and Kemp, 2002). Likewise, a restrictive policy of permits and licenses that hinders the mobility of researchers to the private sector also has a negative impact on activity (Beraza and Rodríguez, 2011).

In unfavorable contexts for entrepreneurship, the creation of spin off requires as a previous step the promotion of an entrepreneurial culture among university staff (Pirnay, 2001). Research results susceptible to commercial exploitation do not arise spontaneously. Ideas must be evaluated to determine their commercial viability. Moreover, university and inventors of the idea must support the project so that a spin off company could be generated. The ideas detected and supported can be diverse, have more or less success and the university will maintain with these links of different intensity (Lockett et al., 2003; Wright et al., 2004; Siegel et al., 2003; Shane, 2004; Clarysse et al., 2005; Beraza and Rodríguez, 2011). 
In this sense, Rodeiro et al., (2010) indicate that the use of programs for the creation of spin off companies has been extended in the university environment, research in this topic plays an important role since the main weaknesses of the spin off after its foundation and that prop up its growth as a company. Although the entrepreneurial university opens new opportunities for social progress through a rapid and effective commercial application of scientific knowledge, it also poses hidden costs, which is why it is interesting to advance in the knowledge of the university's direct involvement in the entrepreneurial activity.

The change in public policy with the Science and Technology Law allows the participation of academic entrepreneurs in the creation of spin offs, is a first step that opens the opportunity to commercialize the research results generated in HEIs and PRCs. However, there are major challenges inside the institutions that can be summarized in three points: first, generating clear and effective internal regulations and processes in the management of intellectual property and commercialization of development; , second having specialists in the areas of TT at HEIs and PRCs to generate capabilities, confidence and acquire results and third, business education and entrepreneurial training of the community so they can generate the skills of management and implementation of business initiatives. The governance, support and priority of these processes depends on decision-makers to be translated into concrete actions and results. Valuing the incentive scheme is also essential to establish the path for a culture and interest in the topics of knowledge commercialization.

In Mexico, the influence of other regions created the conditions for the emergence of different initiatives, where two phases can be identified: first, in the nineties, there were some initiatives to link academiabusiness and the emergence of some incubators where efforts were isolated and led by HEIs and PRCs, materialized in the TBE Incubators Program that was interrupted in 1997 due to the lack of skills to support companies, as well as rigidity in management and financing mechanisms for, so few remained active.

Starting in 2001, public policies aimed for promoting technological transfer and innovation began to be designed from a systemic approach. Systemic strategies to support innovative companies were created through different mechanisms, such as the Business Accelerator network, entrepreneur programs, seed capital, the National Incubator System, clusters, technology parks and TTO, etc.

In this phase, the creation and promotion of innovative activity becomes a fundamental axis of the strategy of public policy in Science and Technology. The creation of the National Business Incubation System in 2004 made it possible until 2014 to create 500 incubators, only $4.2 \%$ were high-tech. However, in Mexico, science and technology programs did not have an explicit orientation to the development of new TBE (Almeida, et al., 2011; OECD, 2012). According to Kantis et al. (2015), Mexico is the second country in Latin America to undertake below Chile. Although the OECD (2012) considers that in Mexico the main objective of incubator programs was not necessarily to support entrepreneurship but rather the issue of unemployment by supporting skilled labor.
Subsequently, with the emergence in 2013 of the National Institute of the Entrepreneur (Inadem), the characterization was changed to denominate high-impact and traditional incubators, supports began to be systematically articulated, which included strategies not only for financing, understanding it as a credit or access to government resources via call, but other alternatives were designed to access economic resources for the development of business initiatives, including non-economic resources. The incorporation of innovation as part of public policy faced barriers associated with regulation of stakeholders of the innovation system have legally. It is not until 2015 that the legal barriers are removed (Hernandez-Mondragon et al., 2016), however its implementation within the HEIs and PRCs has been very diverse.

Among the findings found through the analysis of the literature, as well as empirical contributions, it is highlighted that there is a positive and statistically significant relationship between the creation of spin offs and the tradition and experience of the university in carrying out entrepreneurial activities, access to financial resources for R\&D and innovation, and the presence and effective experience of TTO at the university (Beraza and Rodríguez, 2011).

There are still legal gaps in university regulations, as not all have issued spin off companies The need to give flexibility to HEIs and PRCs personnel, which constitutes an incentive for the generation of companies. An effective application and implementation of the changes in the Science and Technology Law is required, largely due to the lack of an entrepreneurial culture in the academy. (Pérez \& Calderón, 2019). Although in general an attitude of support for academic entreprenurs predominates among universities, but when comes to solving or investing in spin offs, these gaps reappear, requiring people to assume proactive roles as champions, not just from entrepreneurs. The need to promote programs for the creation of high impact TBE companies is a mechanism that will allow the valuation of the knowledge generated in HEIs and PRCs.

The change in public policy with the Science and Technology Law, allows the participation of academics in the development of spin offs, is the first step that opens the opportunity to commercialize the research results generated in HEIs and PRCs.

However, there are greater challenges within the institutions that can be summarized in four parts: first corresponds to the generation of clear and effective internal regulations and processes in the management of intellectual property and the commercialization of developments; second having specialists in the areas of TT within the HEIs and PRCs to generate capacities; third, in contributing to the entrepreneurial and entrepreneurial training of the community so that the management and implementation competencies of business initiatives can be generated, and fourth, the governance, support and priority of these processes depend on decision-makers. To be translated into concrete actions and results. Valuing the incentive scheme is also essential to make way for the generation of a culture and interest in issues of knowledge commercialization. 


\section{Conclusions}

Introducing a business strategy is an imperative for the actions of HEIs and PRCs in the technology market and the generation of new products and services that meet the needs of society. This involves concern for the results and quality control of the research focused on the users of knowledge; managing customer relationships and a service marketing strategy.

However, it is clear that the new national regulations and in each academic institution will require organizational and institutional changes that explicitly incorporate the culture of entrepreneurship and innovation; as well as explicit management policies, in addition to adjustments to public policy that promote technological entrepreneurship from the academy, that consolidate the entrepreneurial and innovation culture, which also entail the need for adjustments to public policy and the generation of a industry and robust markets for technology-based companies.

Furthermore, the HEIs and PRCs must consider, in addition to the regulatory framework, the design and implementation of policies for the creation of spin off companies, as these are the result of a system that links culture of entrepreneurship and innovation, institutional and organizational capacities to promote TT and a prolonged effort in order to university entrepreneurship generates more and more products with high economic and social impact.

Thus, according to the research objective of identifying the challenges for the generation of university spin off companies in Mexico, we consider that the results obtained allow us to assimilate the available knowledge and help to disseminate results that allow us to establish a starting point to delve into the topic in future investigations, whether in sectoral, regional or national cases.

An element that has come out in several of the entrepreneurial academic interviews is that they promote or participate in spin-off companies since they are perceived as a retirement option due to the precariousness of retirements in Mexico, this should undoubtedly be considered as a strategic policy in HEIs and PRCs for the development of careers of their academics.

\section{References}

Baxter C, Wing, P, Anderson B \& Kayl L (2004). Selection, recruitment and development of the spinout management team, in Tang K, Vohora A. y Freeman R. (Eds.), Taking Research to Market. How to build and invest in successful university spinouts, Euromoney Institutional Investor, London, 88-100.

Beraza J. \& Rodríguez A. (2011). Los programas de apoyo a la creación de spin-offs en las universidades españolas: una comparación Internacional, Investigaciones Europeas de Dirección y Economía de la Empresa, 17 (2), 89-117.

Breschi S \& Malerba F (1997). Sectorial Innovation Systems: Technological Regimes, Schumpeterian Dynamics, and Spatial Boundaries, in Edquist C. (Ed.): Systems of Innovation: Technologies, Institutions and Organizations, Routledge, New York, 130-156.
Bruton G, Ketchen D. \& I. Duane (2013). Entrepreneurship as a solution to poverty", Journal of Business Venturing, 28 (6), 683-689.

Bueno E (2007). La Tercera Misión de la Universidad: El Reto de la Transferencia del Conocimiento, Revista de Investigación en Gestión de la Innovación y Tecnología, 41.

Castillo-Vergara M \& A Alvarez-Marin (2015). La trasferencia de investigación en instituciones de educación superior mediante spin off. Revista Actualidades Investigativas en Educación, 5 (3), $1-23$.

Chesbrough H. (2006). Open innovation: The new imperative for creating and profiting from technology. Harvard Business School Press. Cambridge, MA.

Clark B (1998). Creating entrepreneurial universities organizational pathways if transformation. IAU Press, New York.

Clark B (2004). Sustaining Change in Universities, Society for Research into Higher Education. Open University Press, London.

Clarysse B, Wright M, Lockett A, Van de Velde E \& Vohora A. (2005). Spinning out new ventures: a typology of incubation strategies from European research institutions. Journal of Business Venturing, 20(2), 183-216.

Cooke P. (1992). Regional Innovation Systems: Competitive Regulation in the New Europe. Geoforum, 23, 365-382.

Conceicáo O, Fontes M \& Calapez T (2012). The commercialization decisions of research based Spin-Off: Targeting the market for technologies. Technovation, 32 (1), 43-56.

Delmar F \& Davidsson P (2000). Where do they come from? Prevalence and characteristics of nascent entrepreneurs. Entrepreneurship \& Regional Development, 12 (1), 1-23.

Di Gregorio D, \& Shane S (2003). Why do some universities generate more start-ups than others? Research policy, 209-227.

Edquist C (Ed., 1997), Systems of Innovation: Technologies, Institutions and Organisations, Pinter Publishers London.

Etzkowitz H \& L Leydesdorff (2000). The dynamics of innovation: from national Systems Mode 2 to a Triple Helix of University-Industry-Government relations, Research Policy, 29(2), 109-123.

Etzkowitz H (2008). The triple helix - University-industry-government innovation in action. Routledge: New York.

Etzkowitz, H. (1993). Entrepreneurs from Science: the origins of science-based, Regional Economic Development, 31(1), 326-360.

Etzkowitz H, (1998). The norms of entrepreneurial science: cognitive effects of the new university-industry linkages, Research Policy, 27, 823-833. 
Etzkowitz H, Webster A, Gebhard T \& Cantisano B (2000), The future of the university and the university of the future: Evolution of ivory tower to entrepreneurial paradigm, Research Policy, 29 (2), 313-330.

European Commission (2002) University spin-outs in Europe. Overview and good practice. Office for Official Publications of the European Communities, Luxembourg.

Franklin S, Wright M \& Lockett A (2001). Academic and surrogate entrepreneurs in university spin-out companies. Journal of Technology Transfer, 26(1-2), 127-141.

Freeman C (1987). Technology Policy and Economic Performance: Lessons from Japan. Pinter Publishers, London.

García F, Ramírez G, Dr C, González O \& L Torrejón (2017). Coherencia estratégica del spin off universitarias y su impacto en el contexto mexicano. Retos de la Dirección, 11(.2), 38-55.

Grandi A \& Grimaldi (2005). Academics organizational characteristics and the generation of successful business ideas, Journal of Business Venturing, 20, 821-845.

Grimaldi R, Kenney M, Siegel D, \& Wright M (2011), 30 years after Bayh-Dole: Reassessing academic entrepreneurship. Research Policy, 40 (8), 1045-1057.

Iglesias P, Jambrino C \& Peñafiel A. (2012). Caracterización de las spin-Off universitarias como mecanismo de transferencia de tecnología a través de un análisis de clúster. Revista Europea de Dirección y Economía de la Empresa, 21, 240-254.

Jiménez C, Maculan A, Otálora M, I. Moreira R, \& Castellanos O (2010). Reflexiones sobre los mecanismos de transferencia de conocimiento desde la universidad: El caso de las Spin-offs. Transferencia Universitaria Colombia, 12-14.

Kenney M. \& Patton D. (2011). Does inventor ownership encourage university research-derived entrepreneurship? A six university comparison. Research Policy, 40 88), 1100-1112.

Lockett A, \& Wright M, (2005). Resources, capabilities, risk capital and the creation of university spin-out companies. Research Policy, 34(7), 1043-1057.

Lockett A, Wright M \& Franklin S (2003). Technology Transfer and Universities' Spin-Out Strategies, Small Business Economics, 20 (2), $185-200$

Mowery D \& Sampat B. (2001). University Patents and Patent Policy debates in the USA, 1925-1980. Industrial and Corporate Change, 10 (3), 781-814.

Mustar P (1997). Spin-off enterprises. How French academics create hi-tech companies: the conditions for success and failure. Science and Public Policy, 24 (1), 37-43.
Mustar P (2001). Generating spin-offs from public research: trends and outlook- Science Technology Industry Review, 26, 165-172.

Narváez G,Maridueña M, Chávez J \& M González (2016).Las spin off universitarias: revisión de la literatura sobre la ambigüedad del constructo. Revista Global de Negocios, 4 (7), 95-108.

O’Shea R, Allen P, T. J., Chevalier A, \& Roche F (2005).Entrepreneurial orientation, technology transfer and spinoff performance of U.S. universities. Research Policy, 34, 994-1009.

OECD (1999). University Research in Transition, OECD Publications, Paris.

OCDE (2001). Entrepreneurship, Growth and Policy, Paris: OCDE.

OCDE (2003). Entrepreneurship and Local Economic Development through Entrepreneurship, OCDE, Paris.

Pérez M. \& M. Calderón, 2019, Avances normativos en la creación de empresas spin off universitarias en México, Entreciencias 7 (20), 53-64.

Perkmann M, \& Walsh K, (2007). University-industry relationships and open innovation: Towards a research agenda. International Journal of Management Review, 9 (4), 259-280.

Pirnay F (2001). La valorisation économique des résultats de recherche universitaire par création d'activités nouvelles (spin-offs universitaires): Propositions d'un cadre procédural d'essaimage, Thèse de doctorat ès Sciences de Gestion, Université du Droit et de la Santé - Lille 2, Lille.

Pirnay F, Surlemont B, \& Nlemvo F (2003), Toward a typology of university spin-offs. Small Business Economics, vol. 21, no. 4, pp. 355-369.

Polt W, Rarner C, Gassler H, Schibany A \& Schartinger D (2001). Benchmarking Industry Science Relations: the role of framework conditions. Science and Public Policy, 28(4), 247-258.

Powers J \& McDougal L (2005). University start-up formation and technology licensing with firms that go public: a resource-based view of academic entrepreneurship. Journal of Business Venturing, 20 (3), 291- 311 .

Rasmussen E (2006). Facilitating university spin-off ventures an entrepreneurship process perspective. Trykkeriet Høgskolen i Bodø, Ph.D. dissertation, Bodo Graduate School of Business.

Rasmussen E \& Wright M (2015). How can universities facilitate academic Spin-Offs? An entrepreneurial competency perspective. Journal of Technology Transfer, 1-18.

Roberts E. (1991), Entrepreneurs in high technology. Lessons from MIT and beyond, Oxford University Press, New York.

Rodeiro D, Fernández S, Rodríguez A \& Otero L (2010). Factores determinantes de la creación de spin-offs universitarias. Revista Europea de Dirección y Economía de la Empresa, 1, 47-68. 
Santamaria C, \& I Brunet (2007). Creación de empresas y spin-off universitarias en México, Revista Iberoamericana para la Investigación y el Desarrollo Educativo, 5 (9).

Shane S (2004), Academic Entrepreneurship. University Spinoffs and Wealth Creation Edward Elgar Publishing, Cheltenham.

Siegel D, Wright M, \& Lockett A (2007), The rise of entrepreneurial activity at universities: Organizational and societal implications, Industrial and Corporate Change, 16 (4), 489-504.

Siegel D, Waldman D \& Link A (2003). Assessing the impact of organizational practices on the productivity of university technology transfer offices: an exploratory study, Research Policy, 32 (1), 27-48.

Slaughter S \& Leslie L (1997). Academic capitalism. Politics, Policies and the Entrepreneurial University, John Hopkins University Press, Baltimore.

Slaughter S \& Rhoades G (2004). Academic capitalism and the new economy. Markets, state and higher education. Small Business Economics, 20 (2), 185-200.

Smilor R, 1987. The Art and Science of Entrepreneurship. Ballinger NY.
Stal E, Tales A \& Fujino A (2016). The role of university incubators in stimulating academic entrepreneurship, Revista de Administração e Inovação, 13, 89-98.

Thorburn L (1999). Institutional structures and arrangements at Australian public sector laboratories. Science Technology Industry Review, 26, 121-142.

Thursby J \& Kemp S (2002), Growth and productive efficiency of university intellectual property licensing. Research Policy, 31 (1), 109-124.

Vesper K \& Gartner W (1997). Measuring Progress in Entrepreneurship Education. Journal of Business Venturing, 12 (5), 403-421.

Vohora A, Wright M \& Lockett A (2004). Critical junctures in the development of university high-tech spinout companies, Research Policy, 33 (1), 147-175.

Walter A, Auer M \& Ritter T. (2006). The impact of network capabilities and entrepreneurial orientation on university Spin-Off performance. Journal of Business Venturing, 21 (4), 541-567.

Wright M, Birley S \& Mosey S. (2004). Entrepreneurship and University Technology Transfer. Journal of Technology Transfer, 29 (3-4), 235-246. 
